\title{
Carcinoma of the lung: warts and all
}

\author{
A F Markham
}

It is always a salutary experience to be confronted by one's own ignorance. The consequences, however, can often be worthwhile. In my own case, the paper by Soini et al on pp 887-93 of this issue of Thorax ${ }^{1}$ represents a good example of this. The issues it raises should certainly provide food for thought for a wide range of respiratory physicians, other clinicians, pathologists, and medical scientists.

Firstly, I should confess to the many misconceptions under which I first read the paper by Soini et al. I have followed the debate and controversies surrounding the role of human papilloma viruses (HPVs) in squamous cell carcinoma of the cervix for the last decade $^{2}$ at a very superficial level. Initially, much of that controversy was fuelled by technical difficulties in reproducibly detecting low levels of viral DNA in clinical specimens during the era before polymerase chain reaction (PCR). Even when these practical problems were surmounted, the causative role of HPV and, in particular, the high risk strains HPV 16 and 18, remained controversial because they were almost certainly not present in all squamous cell cancers. The current consensus seems to be that HPV16/18 (or sometimes 31/33) are present in about half of squamous cell carcinomas of the cervix and probably initiate transformation to malignancy in these cases; in other cases the disease may well have arisen secondary to a sporadic mutation event in the p53 gene without the involvement of HPV. The plausibility of this dual mechanism model is strengthened by the fact that both impact directly on p53 protein function. ${ }^{3-5}$ I imagine that this might be the level of understanding of this interesting model of malignancy amongst most respiratory physicians. I was vaguely aware that HPV16/18 had been implicated in the development of squamous cell carcinoma of the oropharynx, ${ }^{6} 7$ upper oesophagus, ${ }^{8}$ and anus. ${ }^{9}$ This was consistent with the presence of squamous epithelium at those sites. I therefore assumed that the Finnish group's work describing the presence of HPV in squamous cell carcinoma (and other cancers) of the lung ${ }^{1}$ was simply another example of a well recognised phenomenon and therefore not of particularly great novelty or importance.

To my surprise, there have in fact been relatively few previous studies of possible involvement of HPV in lung cancer over the past 10 years reported in the world literature. ${ }^{10-22}$ The scarcity of these observations has reduced their impact. The limited published data suggest that HPV is not infrequently present. Given that squamous cell carcinoma represents some $40 \%$ of this most common of human malignancies, these small numbers of observations assume a considerable significance. The findings of Soini et al and others are remarkably consistent with those made by many workers in the cervical cancer field. To a first approximation, bronchial squamous cell carcinoma and other histological types of lung cancer display either the presence of oncogenic HPV species or spontaneous p53 mutation. The fact that Soini et al also found HPV in some lung adenocarcinomas probably need not concern us too greatly at this stage. The complex mixed cellularity in many lung cancers is well recognised, ${ }^{23}$ and the widespread occurrence of p 53 mutation in lung cancer is well known. ${ }^{24}$ The fact that this malignancy is very strongly associated with cigarette smoking is thus hardly surprising. Marinat- ing bronchial epithelial cells which have been infected with a transforming strain of HPV, or have undergone a p53 mutation, in the mixture of carcinogens provided by cigarette smoke, has to be a recipe for disaster.

It is worth digressing briefly to consider the mechanisms by which HPV16/18 are thought to cause transformation of cells. These viruses encode transforming proteins, E6 and E7, which are thought to exert their respective effects by interfering with the function of p53 and Rb tumour suppressor proteins directly. E7 binds directly with $\mathrm{Rb}$ and prevents its function as a regulator of the cell cycle. The action of the E6 proteins is a little more complex. ${ }^{25}$ In the HPV infected cell E6 interacts with a human protein, the E6-associated protein (E6-AP). ${ }^{26}$ E6 and E6-AP are thought to act together as a ubiquitin ligase which recruits a human cellular ubiquitin conjugating enzyme to ubiquitinate $\mathrm{p} 53 .^{27}$ (The actual mechanism may involve ubiquitination of the E6/E6-AP complex which itself transfers the ubiquitin to $\mathrm{p} 53$.) Ubiquitination of a cellular protein targets it for proteolysis. Thus, in a cell infected with HPV, wild type p53 will be rapidly and extensively degraded with the result that the cell effectively has a p53 null phenotype. This draws the two putative aetiologies of squamous cell carcinoma together very clearly. Initial cellular transformation by virtue of loss of p53 function may occur either by mutation in the $\mathrm{p} 53$ gene itself of by destruction of the p53 protein secondary to HPV infection. The fact that some squamous cell carcinomas have both mutant p53 and HPV infection is explicable by the resistance of some p53 mutants to E6 driven proteolysis. ${ }^{28}{ }^{29}$ All these events are now fairly well understood at the molecular level. The functions of p53 and E6 have been widely studied, the human E6-AP gene has been cloned ${ }^{26}$ and expressed to provide protein reagents for experimentation, and several groups $^{30-32}$ are currently identifying ubiquitin conjugating enzymes (UBCs) which target p53. Indeed, the first experiments have been reported in which inhibition of E6-stimulated p53 degradation has been achieved. ${ }^{27}$ This has obvious potential therapeutic possibilities in that treated cells would regain normal p53 function which might reasonably be expected to suppress the malignant phenotype.

What happens next? Obviously it is now essential that the data of Soini et al and their predecessors in the literature are confirmed by others. The high frequency of this disease should mean that this phase is not protracted. Technically this will not be a trivial exercise given the need to detect very low levels of infection by in situ hybridisation or the possibility that minor sequence variation in HPV isolates might cause PCR failures. However, on the assumption that the data are reproducible (and there always tends to be controversy in these exercises because of false negatives), a number of other issues arises. The bronchial epithelium is not classically characterised as squamous. What then is the cell initially infected with HPV? The possibility that these cells are shed from the squamous epithelium of the oropharynx is less convincing because squamous cell carcinoma is found both in the lung peripheries and upper lobes. However, there is a recognised association between oral papillomatosis and squamous cell lung cancer. ${ }^{16}$ Hopefully, the new observa- 
tions will also encourage further studies to confirm convincingly once and for all the role of HPV in carcinoma of other squamous epithelia - the upper oesophagus, the vulva, the penis, and the anus. ${ }^{9}$

Finally, establishing a role for HPV in one of the most common killing human malignancies may encourage the pharmaceutical industry to regard this as a worthwhile drug target. Development of new therapeutic entities for HPV derived cervical carcinoma has not been commercially attractive given the decreasing incidence of this disease as a result of widespread population screening programmes. Similarly, squamous cell carcinoma of the oropharynx, upper oesophagus, and anogenital regions did not represent sufficient numbers of patients to justify the levels of investment the pharmaceutical industry would need to make. Inclusion of bronchial squamous cell carcinoma in the list of HPV based cancers would change these financial considerations completely. The p53 ubiquitination mechanism provides a possible starting point for pharmacological intervention. Ironically, this may provide benefits to another small group of patients which suffers the ravages of HPV. Renal transplant patients, presumably as a result of their immunosuppression, have dreadful problems with papillomatosis and, in particular, patients with 10 year graft survival have a $30 \%$ incidence of squamous cell carcinoma of the skin, as well as considerable risk of lesions in the anogenital tract. Perhaps they will also be the indirect beneficiaries of the intriguing observations of Soini et al.

I have confessed to my own ignorance. With luck the pharmaceutical industry will not be using the same excuse for very much longer. Recent description of a recombinant vaccinia virus encoding papillomavirus E6 and E7 and its use for immunotherapy (in cervical cancer) is particularly timely and exciting. ${ }^{33}$ Furthermore, given that three of the four main "Health of the Nation" national targets for cancers are a $30 \%$ reduction in lung cancer deaths in men (15\% in women) by 2010 , a $20 \%$ reduction in the incidence of invasive cervical cancer by the year 2000 , and a halt in year-on-year increases in the incidence of skin cancer by 2005, perhaps our masters in the R \& D function of the NHS should also be taking the study of HPV rather more seriously.

Research in the author's laboratory is supported by the MRC, Wellcome Trust, West Riding Medical Research Trust, and the Yorkshire Cancer Research Campaign.

Molecular Medicine Unit,

University of Leeds,

Clinical Sciences Building,

St Fames's University Hospital,

Leeds LS9 7TF, UK

1 Soini Y, Nuorva K, Kamel D, Pöllänen R, Vähäkangas K, Lehto V, et al. Presence of human papillomavirus DNA and abnormal p53 protein accumulation in lung carcinoma. Thorax 1996;51:887-93.

2 zur Hausen H. Papillomaviruses in human cancer. Cancer 1987;59:16921696.

3 Mullokandov MR, Kholodilov NG, Atkin NB, Burk RD, Johnson AB, Klinger HP. Genomic alterations in cervical carcinoma: losses of chromosome
heterozygosity and human papilloma virus tumour status. Cancer Res heterozygosity and

4 Crook T, Wrede D, Vousden KH. p53 point mutation in HPV negative human carcinoma cell lines. Oncogene 1991;6:873-5.
5 Crook T, Wrede D, Tidy JA, Mason WT, Evans DJ, Vousden KH. Clonal p53 mutation in primary cervical cancer: association with human p53 mutation in primary cervical cancer: association

6 Syrjanen S, Syrjanen K, Mantyjarvi R, Collan Y, Karja J. Human papillomavirus DNA in squamous cell carcinomas of the larynx demonstrated by in situ DNA hybridisation. F Otorhinolaryngol 1987;49:175-86.

7 Brachman DG, Graves D, Vokes E, Beckett M, Haraf D, Montag A, et al. Occurrence of p53 gene deletions and human papilloma virus infection in human head and neck cancer. Cancer Res 1992;52:4832-6.

8 Kulski J, Demeter T, Sterrett GF, Shilkin KB. Human papillomavirus DNA in oesophageal carcinoma. Lancet 1986;ii:683-4.

9 zur Hausen H. Viruses in human cancers. Science 1991;254:1167-73.

10 Stremlau A, Gissmann L, Ikenberg H, Stark M, Bannasch P, zur Hausen H. Human papillomavirus type 16 related DNA in an anaplastic carcinoma of the lung. Cancer 1985;55:1734-40.

11 Syrjanen KJ, Syrjanen SM. Human papillomavirus DNA in bronchial squamous cell carcinomas. Lancet 1987;i:168-9.

12 Syrjanen K, Srjanen S, Kellokoski J, Karja J, Mantyjarvi R. Human papillomavirus (HPV) type 6 and 16 DNA sequences in bronchial squamous cell carcinomas demonstrated by in situ DNA hybridisation. Lung 1989; 167:33-42.

13 Bejui-Thivolet F, Chardlonnet Y, Patricot LM. Human papillomavirus type 11 DNA in papillary squamous cell lung carcinoma. Virchows Arch $A$ Pathol Anat Histopathol 1990;417:457-61.

14 Bejui-Thivolet F, Liagre N, Chignol MC, Chardonnet Y, Patricot LM. Detection of human papilloma virus DNA in squamous bronchial metaplasia and squamous cell carcinomas of the lung by in situ hybridisation using biotinylated probes in paraffin-embedded specimens. Human Pathol 1990;21:111-6.

15 Kulski JK, Demeter T, Mutavdzic S, Sterrett GF, Mitchell KM, Pixley EC. Survey of specimens of human cancer for human papillomavirus types 6/11/16/18 by filter in situ hybridisation. Am f Clin Pathol 1990;94:566-70.

16 Guillou L, Sahli R, Chaubert P. Squamous cell carcinoma of the lung in a non-smoking, nonirradiated patient with juvenile laryngotracheal papillomatosis. Evidence of human papillomavirus-11 DNA in both carcinomia and papillomas. Am $\mathcal{F}$ Surg Pathol 1991;15:891-8.

17 Yousem SA, Ohori NP, Sonmez-Alpan E. Occurrence of human papillomavirus DNA in primary lung neoplasms. Cancer 1992;69:693-7.

18 Popper HH, Wirnsberger G, Juttner-Smolle FM, Pomgratz MG, Sommersgutter $M$. The predictive value of human papilloma virus (HPV) typing in the prognosis of bronchial squamous cell papillomas. Histopathology 1992; the prognosis

19 Popper HH, El-Shabrawi Y, Wockel W, Hofler G, Kenner L, Juttner-Smolle FM, et al. Prognostic importance of human papilloma virus typing in squamous cell papilloma of the bronchus. Human Pathol 1994;25:1191-7.

20 Xing LQ, Liu HR, Si JY. Analysis of the characteristics of human papilloma virus infection in 85 neoplasms of the respiratory system in adult patients. Chinese f Oncol 1994;16:424-7.

21 Kinoshita I, Dosaka-Akita $\mathrm{H}$, Shindoh $M$, Fujino $M$, Akie K, Kato M, et al. Human papillomavirus type $18 \mathrm{RNA}$ and E6-E7 mDNA are detected in squamous cell carcinoma and adenocarcinoma of the lung. Br $\mathcal{f}$ Cancer 1995;71:344-9.

22 Nuorva K, Soini Y, Kamel D, Pollanen R, Bloigu R, Vahakangas K, et al. P53 protein accumulation and the presence of human papilloma virus DNA in bronchiolo-alveolar carcinoma correlate with poor prognosis. Int $\mathcal{f}$ Cancer 1995;64:424-9.

23 Mooi WJ. Common lung cancers. In: Hasleton PS, ed. Spencer's pathology of the lung. 5th edn. New York: McGraw-Hill, 1996:1009-64.

24 Sundaresan V, Rabbitts PH. Genetics of lung tumours. In: Hasleton PS, ed. Spencer's pathology of the lung. 5th edn. New York: McGraw-Hill, 1996:987-1008

25 Scheffner M, Werness BA, Huibregtse JM, Levine AJ, Howley PM. The E6 oncoprotein encoded by human papillomavirus types 16 and 18 promotes the degradation of p53. Cell 1990;63:1129-36.

26 Scheffner M, Huibregtse JM, Vierstia RD, Howley PM. The HPV-16 E6/E6-AP complex functions as a ubiquitin-protein ligase in the ubiquitination of p53. Cell 1993;75:495-505.

27 Rolfe M, Beer-Romero P, Glass S, Eckstein J, Berdo I, Theodoras A, et al. Reconstitution of p53-ubiquitinylation reactions from purified components: the role of human ubiquitin conjugating enzyme UBC4 and E6 associated protein (E6AP). Proc Natl Acad Sci USA 1995;92:3264-8.

28 Medcalf EA, Milner J. Targeting and degradation of p53 by E6 of human papillomavirus type 16 is preferential for the $1620^{+} \mathrm{p} 53$ conformation. Oncogene 1993;8:2847-51.

29 Molinari M, Milner J. P53 in complex with DNA is resistant to ubiquitin-dependent proteolysis in the presence of HPV-16 E6. Oncogene 1995;10:1849-54.

30 Blumenfeld N, Gonen H, Mayer A, Smith CE, Siegel NR, Schwartz AL, et al. Purification and characterisation of a novel species of ubiquitin-carrier protein E2 that is involved in degradation of non-" $\mathrm{N}$-end rule" protein substrates. $\mathcal{F}$ Biol Chem 1994;269:9574-81

31 Scheffner M, Huibregtse JM, Howley PM. Identification of a human ubiquitin-conjugating enzyme that mediates the E6-AP-dependent ubiquitination of p53. Proc Natl Acad Sci USA 1994;91:8797-801.

32 Robinson PA, Leek JP, Thompson J, Carr IM, Bailey A, Moynihan TP, et al. A human ubiquitin conjugating enzyme, L-UBC, maps in the Alzheimer's disease locus on chromosome 14q24-3. Mammalian Genome 1995;6:72531 .

33 Borysiewicz LK, Fiander A, Nimako M, Man S, Wilkinson GWG, Westmoreland D, et al. A recombinant vaccinia virus encoding human papillomavirus types 16 and 18, E6 and E7 proteins as immunotherapy for cervical cancer. Lancet 1996;347:1523-7. 